\title{
Biofilm Growth Characteristics at Different Diesel Leakage Concentration
}

\author{
Fang Liu, Wei Yang, HuiYun Zhong, JinJin Lu, and Chaocheng Zhao
}

\begin{abstract}
Petroleum products leakages result in important effects on the normal operation of circulating cooling water system. However, relatively little research has been done to explore effects of petroleum products leakages on biofilm growth characteristics. In this study, diesel as the experimental subject representing petroleum products, effects of diesel addition on biofilm growth characteristics were investigated. Increase of diesel addition led to biofilm EPS increase with diesel concentration less than $200 \mathrm{mg} / \mathrm{L}$, then EPS content were kept relatively stable with diesel concentration more than 200 $\mathrm{mg} / \mathrm{L}$. Protein contents were found at relatively higher levels than polysaccharides in the biofilm with diesel concentration more than $200 \mathrm{mg} / \mathrm{L}$. Expect for $100 \mathrm{mg} / \mathrm{L}$ diesel, increasing diesel concentration enhanced biofilm detachment ratio with respect to the control test. Although biofilm wet weight tended to increase with diesel concentration rising from 0 to $1500 \mathrm{mg} / \mathrm{L}$ there was a marked reduction in lipid phosphorus content with increase of diesel concentration from 200 to $1500 \mathrm{mg} / \mathrm{L}$. The reduction indicated that diesel was toxic to microbial population in biofilm.
\end{abstract}

Index Terms-Circulating cooling water, leakage, diesel, biofilm, growth characteristics.

\section{INTRODUCTION}

In the circulating cooling water system of petroleum refineries in China, petroleum products leakages generally exist. Poor quality of heat exchangers, outdated hermetic sealing technique, aging pipelines, improper operation and other reasons all can lead to petroleum products leakages. In order to reduce the leakage hazards, refineries usually increase pollutants emissions, displace the systems and reduce the concentration index [1]. The above operation modes undoubtedly intensify the contradiction between water consumption increasing and water resources shortage. Further, if sewage from circulating cooling water is discharged into natural water, residues of petroleum products will cause biohazardous effects on human beings as well as other living organisms in the environment. So, petroleum products leakages should be paid enough attention.

Biofilm in general is defined as the accumulation of deposits associated with living organisms growth such as microorganisms (bacteria and algae) and macro-organisms (sponge species, etc.), which are very common, especially in industrial cooling towers [2]. Biofilm can cause equipment

Manuscript received November 14, 2012; revised February 3, 2013. This research was financially supported by National Natural Science Foundation of China (project 20707040 and 21077133) and the Fundamental Research Funds for the Central Universities.

The authors are with the College of Chemical Engineering, China University of Petroleum, Qingdao 266555 (e-mail: liufangfw@163.com, yangwei6835@163.com, huiyun0102@126.com). damage through corrosion, down time, decrease energy efficiency due to increasing hydraulic pressure (pumping costs), local clogging of cooling towers and increasing heat transfer resistance [3]. According to researcher's result [4], almost half of the defects in cooling water systems were due to problems related to biofilm. Biofilm problems do not arise from microorganisms which have suddenly invaded the system, but are much more likely to be caused by an increase in nutrient concentration or an absence of inhibiting factors. Wijeyekoon et al. manifested that there was obvious difference on structure, porosity and distribution of biofilms formed under different organic carbon concentrations [5]. Shafahi et al. found that organic carbon concentrations affected biofilms' thickness and pore structure directly [6].

Biofilm is composed of microbial cells and extracellular polysaccharide structures (EPS). EPS can enhance biofilm resistance to environmental stress and antimicrobial agents [7]. The production of EPS is known to be affected by nutrients status of the growth medium and the availability of carbon. For these reasons, the biofilm which grows at different nutrient levels in the circulating cooling water system will have the different EPS production and structure. There are contradictory reports in the literature about EPS composition especially with the ratio of protein to polysaccharide (PR/PS). Some researchers indicated that certain EPS from wastewater biofilms had a higher concentration of proteins than polysaccharides and some others showed that polysaccharides were found to be dominant in the biofilm [8], [9].

A better understanding of biofilm behavior is particularly important due to many serious problems associated with biofilm presence. Once developed, the biofilm was harder to be removed completely [10], [11]. Mechanical forces is a parameter often involved in biofilm removal, since the application of sole chemical agents tended to leave the biofilm intact when no mechanical treatment was implemented in the control process [12]. An important biofilm feature involved in the recalcitrance to current biofilm control procedures is the mechanical stability. If petroleum products leak into the circulating cooling water, leakages will affect the biofilm mechanical stability by influencing biofilm structure. This problem is worth studying for ensuring normal operation of circulating cooling water system.

Understanding the contribution of petroleum products leakage to biofilm development are important requirements for cooling water system management strategies. However, little experimental research has been done about the effects of petroleum products leakage on controlling biofilm formation 
and development in the circulating cooling water system. This study was therefore carried out to investigate the effect of petroleum products leakages on biofilm growth characteristics in a laboratory-scale circulating cooling water system.

\section{MATERIALS AND MethodS}

\section{A. Biofilm Formation}

Representative industrial water from recirculating cooling water system of refining corporation was used as inoculums for research purposes. The inoculating bacteria from suspended microorganism in the recirculating cooling water system were cultivated in individual $2.0 \mathrm{~L}$ glass beaker filled with medium of nutritive proportion, which were prepared by adding to each liter of tap water with a measured amount of carbon source (glucose), ammonia nitrogen (ammonia sulfate) and TP (sodium hydrogen phosphate). In the medium, the ratio $\mathrm{C} / \mathrm{N} / \mathrm{P}$ was 50/10/1. All the media were sterilized at 121 ${ }^{\circ} \mathrm{C}, 15$ psi for $20 \mathrm{~min}$. During experimental period, temperature of water bath for microorganism' s growth was maintained at $32 \pm 1^{\circ} \mathrm{C}$ by a thermostat, $\mathrm{pH}$ remained between 7 and 9 , steady rotating speed of $100 \mathrm{rpm}$ was implemented by mechanical stirrers attached to model device to ensure uniform nutrient solutions and shear on biofilm. Dissolved oxygen concentration was more than $2 \mathrm{mg} / \mathrm{L}$ consistently.

Standard stainless steel coupons (AISI 304, 50×25×2 $\mathrm{mm}^{3}$ ) were used for microorganism's attachment and consequent biofilm formation. Before used, the coupons were washed in distilled water and air dried at room temperature. The cleaned coupons were stored in desiccators. Three stainless-steel coupons were used in every experiment. The biofilms were allowed to grow for 7 days in order to obtain steady-state biofilms.

\section{B. Addition of Diesel}

After steady-state biofilms were obtained, diesel oil was added into the reactors. The diesel additions were 0,100 $\mathrm{mg} / \mathrm{L}, 200 \mathrm{mg} / \mathrm{L}, 500 \mathrm{mg} / \mathrm{L}, 800 \mathrm{mg} / \mathrm{L}, 1000 \mathrm{mg} / \mathrm{L}, 1300$ $\mathrm{mg} / \mathrm{L}$ and $1500 \mathrm{mg} / \mathrm{L}$, respectively. The diesel density is 0.84 $\mathrm{g} / \mathrm{cm}^{3}$ at $20^{\circ} \mathrm{C}$ and the viscosity is $3.26 \mathrm{~mm}^{2} / \mathrm{s}$ at $35^{\circ} \mathrm{C}$. Zinc and iron contents in diesel are $2.38 \mu \mathrm{g} / \mathrm{g}$ and $0.91 \mu \mathrm{g} / \mathrm{g}$, respectively.

\section{Biofilm Sampling for Phenotypic Characterization}

The biofilm on the stainless steel coupons was removed using a stainless steel scraper and afterwards resuspended in $50 \mathrm{~mL}$ of buffer solution $\left(2 \mathrm{mM} \mathrm{Na}_{3} \mathrm{PO}_{4}, 2 \mathrm{mMNaH}_{2} \mathrm{PO}_{4}, 9\right.$ $\mathrm{mM} \mathrm{NaCl}$ and $1 \mathrm{mM} \mathrm{KCl}, \mathrm{pH} 7$ ) and homogenized by vortexing (Heidolph, model Reax top) for $30 \mathrm{~s}$ with $100 \%$ power input, according to the methodology described by Simoes [13]. The homogenized biofilm suspensions were then phenotypically characterized in terms of extracellular polymeric substances (EPS) content (proteins and polysaccharides).

\section{EPS Extraction}

EPS extraction of the biofilm was carried out using formaldehyde plus sodium hydroxide $(\mathrm{NaOH})$ assay according to the procedure described by Liu and Fang [14].

\section{E. Polysaccharide Content Quantification}

The polysaccharide content in EPS was measured by the anthrone-sulfuric acid method using glucose as standard [15]. The data represented the mean of three measurements.

\section{F. Protein Content Quantification}

The protein content was determined by the method of Bradford using bovine serum albumin as standard [16]. The data represented the mean of three measurements.

\section{G. Biofilm Detachment}

Biofilm detachment was assessed by means of biofilm weight loss due to biofilm exposure in a rotating device. The stainless steel coupons with biofilm were removed from the $2.0 \mathrm{~L}$ bioreactors and then accurately weighted, marked $\mathrm{W}_{1}$. Afterwards, the coupons were immersed into $0.5 \mathrm{~L}$ vessels containing $0.35 \mathrm{~L}$ distilled water. The coupons with biofilm were rotated at a constant speed of $300 \mathrm{~min}^{-1}$ for $4 \mathrm{~h}$ in the rotating device. At $0.25 \mathrm{~h}, 0.5 \mathrm{~h}, 1 \mathrm{~h}, 1.5 \mathrm{~h}, 2 \mathrm{~h}, 3 \mathrm{~h}$ and $4 \mathrm{~h}$, the coupons with biofilm were removed from the device and then accurately weighted, marked $\mathrm{W}_{2}$. In the end, after 4 hours, the coupons were removed from the device, and then washed away, accurately weighted, last marked $\mathrm{W}_{3}$. So biofilm detachment ratio was described as the following equation:

$$
S=\frac{W_{1}-W_{2}}{W_{1}-W_{3}}
$$

\section{H. Biofilm Wet Weight Quantification}

The biofilm wet weight was calculated as the following equation:

$$
\mathrm{m}=\left(m_{i}-m_{0}\right) / \mathrm{A}
$$

In equation (2), $\mathrm{m}_{\mathrm{i}}$ was the weight of coupon covering the biofilm, $\mathrm{m}_{0}$ was the coupon weight, A was the coupon surface area. The results were expressed as $m g$ per $\mathrm{cm}^{2}$. The data represented the mean of three measurements.

\section{Biofilm Biomass}

The mixture of chloroform, methanol, and deionized water as the extractant to extract phospholipids from biofilm, and then added chloroform and deionized water to achieve stratification with a final ratio of 1:1:0.9. The lipid phase was separated and dried by nitrogen after stratification. The absorbance of the solvent was measured with a spectrophotometer after digestion. The detailed procedures of phospholipid analysis were referred to the reference [17].

\section{J. Image Analysis of Scanning Electron Microscopy}

The biofilm growing to the stable phase was selected. One group was the natural growth sample without diesel addition. And the other group was the sample with $500 \mathrm{mg} / \mathrm{L}$ diesel addition. The microstructure of biofilm was observed by S-4800 cold field emission scanning electron microscopy (SEM). 


\section{RESUlTS AND DisCUSSION}

\section{A. Effects of Diesel Concentration on Biofilm Chemical Composition}

The effects of diesel concentration on biofilm polysaccharide, protein and EPS are shown in Fig. 1.

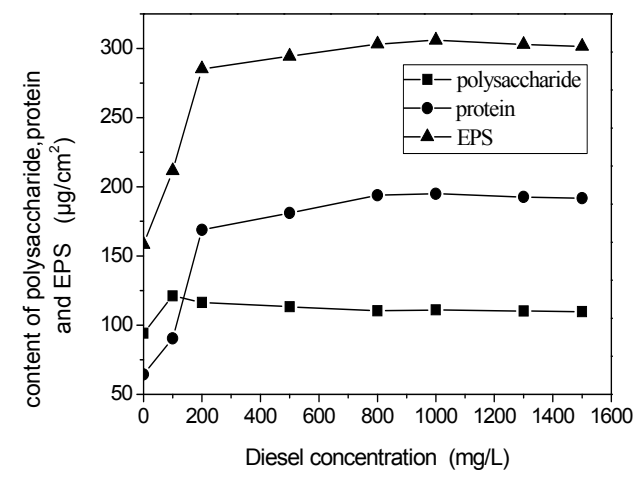

Fig. 1. Effects of diesel concentration on content of polysaccharide, protein and EPS.

Increase of diesel concentration led to increase of protein and EPS content when diesel concentration was less than 200 $\mathrm{mg} / \mathrm{L}$. Protein and EPS contents increased from $64.31 \mu \mathrm{g} / \mathrm{cm}^{2}$ to $168.82 \mu \mathrm{g} / \mathrm{cm}^{2}$ and from $158.42 \mu \mathrm{g} / \mathrm{cm}^{2}$ to $285.27 \mu \mathrm{g} / \mathrm{cm}^{2}$, respectively. Then protein and EPS content were kept relatively stable with diesel concentration more than 200 $\mathrm{mg} / \mathrm{L}$. While polysaccharide content reached the maximum $\left(121.19 \mu \mathrm{g} / \mathrm{cm}^{2}\right)$ when diesel concentration was $100 \mathrm{mg} / \mathrm{L}$, and then decreased slightly from $121.19 \mu \mathrm{g} / \mathrm{cm}^{2}$ to 109.75 $\mu \mathrm{g} / \mathrm{cm}^{2}$ with diesel concentration increasing from $100 \mathrm{mg} / \mathrm{L}$ to $1500 \mathrm{mg} / \mathrm{L}$. The obtained results suggested that diesel addition had the important impact on contents of polysaccharide, protein and EPS in biofilm at low diesel concentration. The ratio of protein to polysaccharide (PR/PS) was the key parameter for indicating biofilm structural characteristics [18]. Although polysaccharides have often been regarded as the most important extracellular components [19], proteins were found at relatively higher levels than polysaccharides in the biofilm with diesel concentration more than $200 \mathrm{mg} / \mathrm{L}$ in this study. PR/PS ranged from 0.68 to 1.75 when diesel concentration increased from 0 to $1500 \mathrm{mg} / \mathrm{L}$ (Fig. 2). This observation was consistent with work by CELMER who also observed that protein was the main component of biofilms [20]. Although diesel concentration has the important effect on biofilm chemical composition, PR/PS kept stable from 1.76 to 1.75 when diesel concentration increased from 800 to $1500 \mathrm{mg} / \mathrm{L}$. The obtained results suggested that the biofilm structural was relatively stable after diesel concentration larger than 800 $\mathrm{mg} / \mathrm{L}$.

\section{B. Effects of Diesel Concentration on Biofilm Detachment Ratio}

Biofilm mechanical strength was assessed by biofilm detachment ratios on coupons at different times. Biofilm detachment ratios at different diesel concentration are shown in Fig. 3. The existence of shear stress force was higher than the one under which the biofilm was formed caused biofilm removal. It manifested that the biofilm removal was dependent on the hydrodynamic conditions. Fig. 3 shows that the increase in detachment time leads to an increase in biofilm detachment ratios, however, the biofilm detachment ratios keeps relatively stable after 2 hours. The biofilm mechanical stability, i.e., the behavior of biofilm facing external stress mechanical conditions, was of great impact for both wanted and unwanted biofilms [21]. In this study, the biofilm mechanical stability was assessed by submitting biofilm to the shear stresses, which could weaken the biofilm structure and promote detachment. The biofilm formed on the coupons of the rotating device prior to diesel addition was characterized in order to determine the inherent biofilm mechanical stability, since detachment processes may be dependent on it.

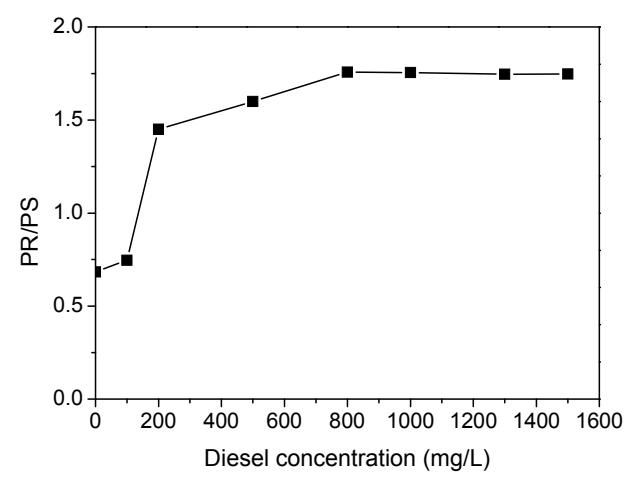

Fig. 2. Effects of diesel concentration on the ratio of protein to polysaccharide (PR/PS)

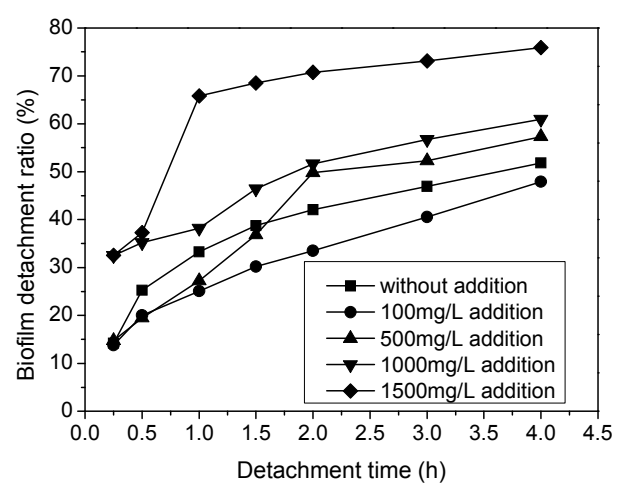

Fig. 3. Effects of diesel concentration on biofilm detachment ratio

The comparison of biofilm detachment ratios at different diesel concentrations, for the same shear stress force, showed that diesel had the important effect on biofilm detachment. Expect for $100 \mathrm{mg} / \mathrm{L}$ diesel concentration, increasing diesel concentrations enhanced biofilm detachment ratios with respect to the control test. It reflected that small content of diesel mainly made the adhesion between biofilm and coupons closer. When diesel of larger concentration was added, diesel and biofilm joined together into massive structure, which was easy to be peeled off. Moreover, larger diesel concentration may lead to the increase of biofilm thickness, which resulted in anaerobic conditions development within the biofilm. Because of the biofilm thickness and the activity of anaerobic species, the biofilm detached and sloughed off from the coupons. The results obtained from Fig. 3 can also be manifested by image analysis of the biofilm (Fig. 4. to Fig. 6.). 

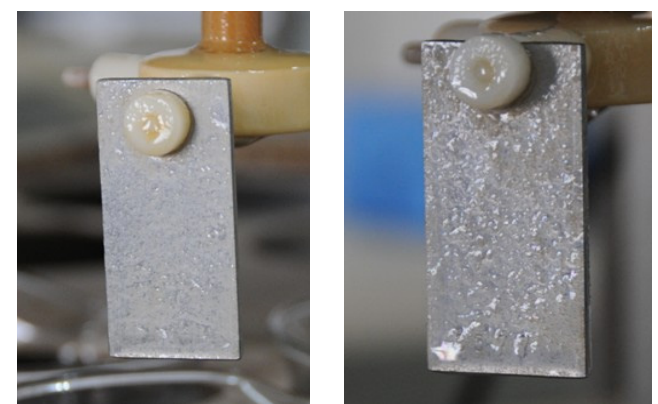

(a) coupon without diesel addition (b) coupon with $500 \mathrm{mg} / \mathrm{L}$ diesel addition

Fig. 4. Coupon pictures at different diesel addition

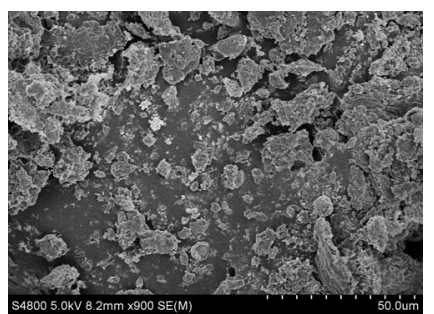

(a) without diesel addition Fig. 5. Biofilm SEM pictures at 900 times magnification

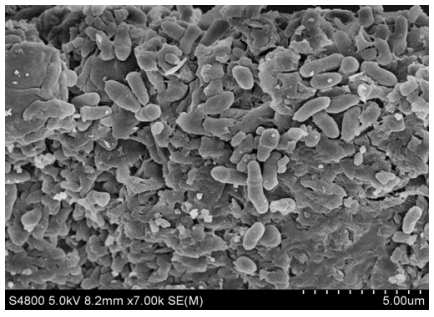

(a) without diesel addition

Fig. 6. Biofilm SEM pictures at 7000 times magnification

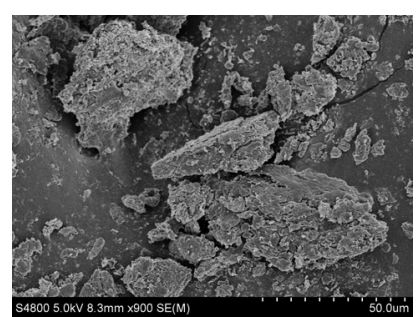

(b) $500 \mathrm{mg} / \mathrm{L}$ diesel addition

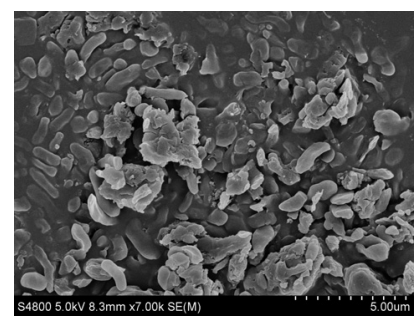

(b) $500 \mathrm{mg} / \mathrm{L}$ diesel addition

It was obvious from Fig. 4 (a) to Fig. 6(a) that without diesel addition, the structure of biofilm was loose and fragmentary. After adding 500mg/L diesel, the structure became large blocks and porosity became smaller (Fig. 4(b) to Fig. 6(b)), which might be explained that diesel could adsorb and adhere to biofilm. According to Fig.3, in a short period of stirring, the detachment ratios of biofilm with $500 \mathrm{mg} / \mathrm{L}$ diesel were smaller than that in control test. However, when detachment time was longer than $2 \mathrm{~h}$, the detachment ratios became larger, even exceeded that of without diesel addition.

\section{Effects of Diesel Concentration on Biofilm Wet Weight and Biomass}

Fig. 7 shows that the biofilm wet weight tends to increase with diesel concentration changing from 0 to $1500 \mathrm{mg} / \mathrm{L}$. Because of its viscosity, diesel could adsorb suspended matters and biofilm, which resulted in a mixture of material fouling and bacterial biofilm formation. As mentioned in Fig.1, the increase of diesel concentration resulted in EPS rising. EPS was highly hydrated because it can incorporate large amounts of water into structure by hydrogen bonding [22]. The water increase also led to biofilm wet weight increasing.

The diesel addition has the obvious effect on the lipid phosphorus content (Fig. 8). The lipid phosphorous content in biofilm reached the largest value (about $1.0 \mu \mathrm{gP} / \mathrm{cm}^{2}$ ) when diesel concentration was $200 \mathrm{mg} / \mathrm{L}$. Diesel oil is a compound found as a component of petroleum hydrocarbons. It is a complex mixture of paraffins, cyclic alkanes and aromatic compounds having low water solubility, high adsorption coefficient and high stable aromatic ring [23]. The obtained results in Fig. 8 showed that hydrocarbons in diesel at low concentration provided microorganism's carbon sources to promote their growth. And then, there was a marked reduction in the lipid phosphorus content with increase of diesel concentration from 200 to $1500 \mathrm{mg} / \mathrm{L}$. The reduction, which indicated that diesel was toxic to part of the microbial population in biofilm, was related to the intensity of diesel concentration. Several authors have indicated that the hydrocarbons in petroleum had a toxic effect on the soil microbial community, especially presenting at high concentrations, which caused changes in the structure of the microbial community and a general decrease in the diversity and number of microorganisms [24],[25].

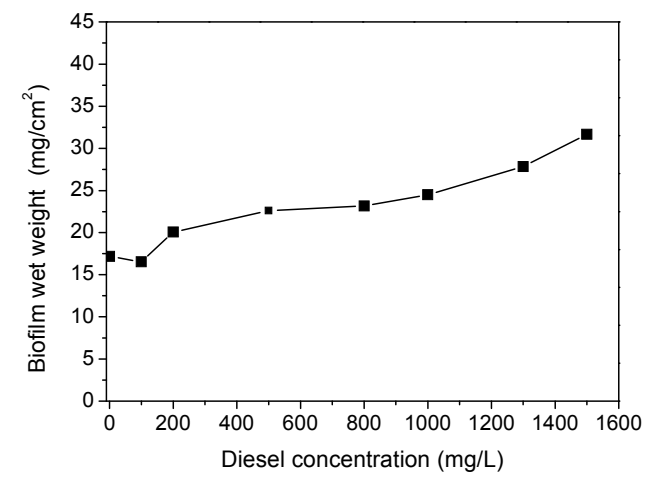

Fig. 7. Effects of diesel concentration on biofilm wet weight

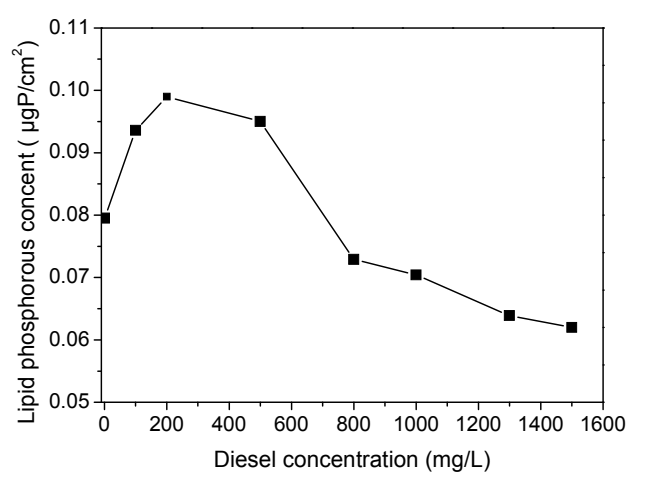

Fig. 8. Effects of diesel concentration on lipid phosphorus in biofilm

\section{CONCLUSIONS}

The diesel addition has the important impact on biofilm EPS composition. This implied that EPS composition was variable and was related to bacteria physiological state and the operating conditions under which biofilm was developed. The small content of diesel made the adhesion between biofilm and coupons closer. When diesel of larger concentration was added, diesel and biofilm joined together into massive structure, which was easy to be peeled off. Although the biofilm wet weight tended to increase with diesel addition, the lipid phosphorous content in biofilm reached the largest value when diesel concentration was 200 $\mathrm{mg} / \mathrm{L}$, and then there was a marked reduction in the lipid 
phosphorus content with increase of diesel concentration from 200 to $1500 \mathrm{mg} / \mathrm{L}$. The reduction, which indicated that diesel was toxic to part of the microbial population in biofilm, was related to the intensity of diesel concentration.

\section{REFERENCES}

[1] H. Y. Yang and W. X. Zhu, "Treatment of circulating cooling water by leakage pollution", Chemical Engineer, vol. 8, pp. 44-46, March 2004

[2] T. R. Bott, "Fouling of heat exchangers," S. W. Churchill, editor. Chemical Engineering Monographs, vol. 26, pp. 224-239, Amsterdam, Elsevier, Netherlands, 1995.

[3] T. R. Bott, "Techniques for reducing the amount of biocide necessary to counteract the effects of biofilm growth in cooling water systems," Appl. Therm. Eng., vol.18, pp.1059-1066, November 1998.

[4] G. G. Geesey and J. D. Bryers, "Biofouling of engineered materials and systems," J. D. Bryers, editor. Biofilms II, Process Analyses and Applications, pp.237-279, NewYork, Wiley-Liss, USA, 2000.

[5] S. Wijeyekoon, T. Mino, H. Satoh, and T. Matsuo, "Effects of substrate loading rate on biofilm structure," Water Res., vol. 38, pp. 2479-2488, May 2004.

[6] M. Shafahi and K. Vafai, "Biofilm affected characteristics of porous structures," Int. J. Heat Mass Tran., vol. 52, pp. 574-581, Jan. 2009.

[7] Y. Lequette, G. Boels, M. Clarisse, and C. Faille, "Using enzymes to remove biofilms of bacterial isolates samples in the food industry," Biofouling, vol. 4, pp. 421-431, May 2010.

[8] I. W. Sutherland, "Structure function relationship in microbial exopolysaccharides," J. Biotech. Adv., vol.12, pp. 393-448, Feb. 1994

[9] P. H. Nielsen, A. Jahn, and R. Palmgren, "Conceptual model for production and composition of exopolymers in biofilms," Water Sci. Technol., vol.36, pp. 11-19, Jan.. 1997.

[10] M. Simões, H. Carvalho, M. O. Pereira, and M. J. Vieira, "Studies on the behaviour of Pseudomonas fluorescens biofilms after ortho-phthalaldehyde treatment," Biofouling, vol. 19, pp. 151-157, Jun. 2003.

[11] M. Simões, M. O. Pereira, M. J. Vieira, "Effect of mechanical stress on biofilms challenged by different chemicals," Water Res., vol. 39, pp. 5142-5152, Dec. 2005.

[12] M .O. Pereira, M. Kuehn, S. Wuertz, T. Neu, and L. Melo, "Effect of flow regime on the architecture of a Pseudomonas fluorescens biofilm," Biotech. Bioeng., vol. 78, pp.164-171, Apr. 2002.

[13] H. Liu and H. H. P. Fang, "Extraction of extracellular polymeric substances (EPS) of sludges," J. Biotechnol., vol. 95, pp. 249-256, May 2002.

[14] A. Laurentin and C. A. Edwards, "A microtiter modification of the anthrone-sulfuric acid colorimetric assay for glucose-based carbohydrates," Anal. Biochem., vol. 315, pp.143-145, Apr. 2003.

[15] M. Bradford, "A rapid and sensitive method for the quantitation of microgram quantities of protein utilizing the principle of protein-dye binding," Anal. Biochem., vol. 72, pp. 248-254, May 1976.

[16] C. Arnaiz, J. C. Gutierrez, and J. Lebrato, "Support material selection for anaerobic fluidized bed reactors by phospholipid analysis,",Biochem. Eng. J., vol. 27, pp. 240-245, Jan. 2006.

[17] A.Rochex and J. M.Lebeault, "Effects of nutrients on biofilm formation and detachment of a Pseudomonas putida strain isolated from a paper machine," Water Res., vol. 41, pp. 2885-2892, May 2007.

[18] B. E. Christensen, "The role of extracellular polysaccharides in biofilms," J. Biotechnol., vol. 10, pp. 181-202, 1989.

[19] D. Celmer, J. A. Oleszkiewicz, and N. Cicek, "Impact of shear force on the biofilm structure and performance of a membrane biofilm reactor for tertiary hydrogen-driven denitrification of municipal wastewater," Water Res., vol. 42, pp. 3057-3065, Mar. 2008.
[20] E. H. Poppele, R. M. Hozalski, "Micro-cantilever method for measuring the tensile strength of biofilms and microbial flocs," $J$. Microbiol. Meth., vol. 55, pp. 607-615, Dec. 2003.

[21] I. P. Molobela, "Proteolytic and amylolytic enzymes for bacterial biofilm control," PhD. Faculty of Natural Sciences, University of Pretoria, Pretoria, South Africa, 2010.

[22] J. D. Van Hamme, A. Singh, and O. P. Ward, "Physiological aspects. Part 1 in series of papers devoted to biosurfactants in microbiology and biotechnology," Biotechnol. Adv., vol. 24, pp. 604-620, Aug. 2006.

[23] M. Megharaj, I. Singleton, N. C. McClure, and R. Naidu, "Influence of petroleum hydrocarbon contamination on microalgae and microbial activities in a long-term contaminated soil," Arch. Environ. Contam. Toxicol., vol. 38, pp. 439-445, May 2000.

[24] J. E. Lindstrom, R. B. Barry, and J. F. Braddock, "Long-term effects on microbial communities after a subartic oil spill," Soil Biol. Biochem. vol. 31, pp. 1677-1689, Oct. 1999.

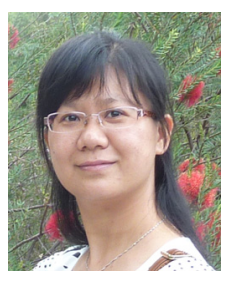

Fang Liu is the $\mathrm{PhD}$ and Associate Professor in Environmental Engineering Major, College of Chemical Engineering, China University of Petroleum, Qingdao.

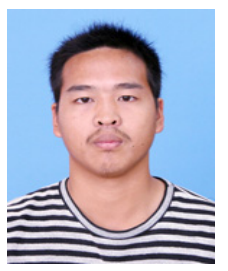

Wei Yang is the graduate student in the College of Chemical Engineering, China University of Petroleum, Qingdao.

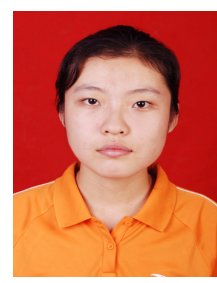

Huiyun Zhong is the graduate student in the College of Chemical Engineering, China University of Petroleum, Qingdao.

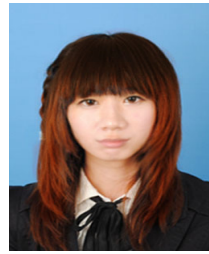

JinJin Lu is the graduate student in the College of Chemical Engineering, China University of Petroleum, Qingdao.

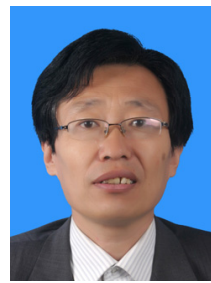

Chaocheng Zhao is the Professor in the College of Chemical Engineering, China University of Petroleum, Qingdao. 